\section{National Academy of}

Sciences. Access: http:

//www.nas.edu/

The National Academy of Sciences (NAS) advises the fecleral government on scientific and technical matters by congressional mandate. Chartered in 1863, NAS includes the National Academy of Engineering (NAE), the Institute of Medicine (IOM), and the National Research Council (NRC). All four organizations share a common entry portal.

Hyperlinks are provided to topical groupings representing NAS' primary areas of research: transportation, education, agriculture, computer science, engineering, physical sciences and mathematics, science and technology policy, life sciences, medicine and health, environment and earth sciences, and behavioral and social sciences. Opportunities for gracluate research and postdoctoral appointments and a career planning section are highlighted from the main page. The Career Planning Center for Beginning Scientists and Engineers is underwritten by the Sloan Foundation.

More than 900 National Academy Press books from the 1980 s and 1990 s have been mounted for free viewing at http://www. nap. edu/readingroom/. The publications are available in a variety of formats: html, pdf, PostScript, ASCII, and DocuWeb, which seems to be the most prevalent. DocuWeb embeds scanned page images in GIF format between top and bottom tables with navigation links. A graphical browser is necessary to view these books, but the format requires no additional software acquisition by the user. The abundance of current scholarly monographs provided is, to my knowledge, without equal on the Internet.

Information about the membership is provided. Access points include an alphabetical listing, discipline grouped subsets, and an institutional list. Entries identify the member's section and year of appointment to the academy, and cite some of the member's scientific achievements. Random sampling indicated citations are only available for individuals appointed since the early 1980 s. A separate search- able clirectory of NAS staff e-mail addresses is available.

NAE has only a skeletal presence. IOM is more fleshed out. Many of the boards within IOM have mounted html versions of abstracts and/or press releases of reports released since 1995. Few complete IOM reports are published on the Web. Navigation of NRC Web space is accomplished primarily through its program units. The Transportation Research Board has its own press, bookstore, and online ordering information.

The site is best viewed with a browser that supports tables, forms, and frames. Care has obviously been taken to reproduce all the navigation options in click maps, navigation buttons, and text links. The overall site is searchable.-George S. Porter, North Carolina State University Libraries; george_porter@ncsu.edu

\section{Noema: The Collaborative Bibliogra- phy of Women in Philosophy. Access.}

http://billyboy.ius.indiana.edu/Womenin Philosophy/WomeninPhilo.html.

The Collaborative Bibliography of Women in Philosophy is an impressive database of more than 10,000 records of works in philosophy by women from ancient history to the present. The scope is international and includes foreign-language materials and Web sites. The database is primarily a list of publications by women, but a number of entries also include secondary sources. The entries are brief and are not annotated, for the most part.

A search for the familiar names in philosophy-Hannah Arendt and Simone de Beauvoir-will result in an impressive list of books and materials by them, and a number of entries with annotations from secondary sources. In addition, the entries for Arendt and Emma Goldman include links to other Internet sites via a link labeled "more information." It would make the project even more impressive if these links continue to grow in number. Currently there are more than 2,000 links from the

Sara Amato is attomated systems librarian at Central Wasbington University; samato@iahoma.cun.edu 
entries, but many of these are just an address to the contributor's or author's name at another Web site.

Searching the database is relatively simple-by author, title, annotation, or all fields. One should select "all fields" due to the low number of annotations. The ability to search by a range of years is particularly useful. A subject search for a topic such as ecofeminism will provide a respectable list of articles, but it does not provide as many as appear in the Pbilosopher's Index or other available indexes.

One criticism of this database is the need for consistency in providing certain data about the women included. Numerous entries cite Ethel M. Kersey's work Women PbilosopbersA Bio-Critical Source Book. It would be helpful, since they appear in Kersey's work, to include a brief one-line statement identifying who they are and when they lived. Another question is why some entries include extensive annotations and others do not.

The Collaborative Bibliography is an ongoing project that will be continually updated, and is to be published in book form by the end of 1996 . As a collaborative project, the more than 100 contributors have done an impressive job of collecting resources by women philosophers. As a catalog of published materials by women in philosophy, it is a valuable starting point for students interested in identifying women philosophers. The ability to locate women authors in a particular time period is also very helpful. However, it is a starting point, and other sources for critical reviews or subject-oriented materials should be consulted.Teresa Fisbel, Macalester College; Fishel@Macalester.edu

Media Research Center. Access: http:// www mediaresearch.org.

The Media Research Center (MRC) is a conservative media watchdog organization that was established in 1987 to "bring political balance to the media." Its founder, Brent Bozell III, is a syndicated author, former president of the $\mathrm{Na}$ - tional Conservative Political Action Committee, and served as Pat Buchanan's financial director during the 1992 presidential campaign. MRC is known for its special studies, its newsletters-MediaWatch, MediaNomics, and Notable Quotables, and its books such as That's the Way It Isn't: $A$ Reference Guide to Media Bias. The Web site provides another means to relay this information. Anyone looking for the conservative viewpoint on a current issue will benefit from visiting this site.

From the main page one may search the site, link directly to selected studies, or use buttons to enter the various divisions. The News Division seeks evidence of liberal bias in newspapers, news magazines, and news programs. Findings are reported in MediaWatch, a monthly newsletter, and made available on the Web. Special reports, such as "The Media and Whitewater," are available as well. Improved values-driven television programming is the goal of the Parents Television Council. An outcome of this special project of the MRC is a comprehensive guide to the content of prime-time television programs, which may be purchased through this site. MediaNomics, a monthly product of the Free Market Project (FMP), reports how business and economic issues are covered by the media. The Election 96 Reality Cbeck reports liberal bias in campaign reporting. This is a $\$ 2.8$ million effort aimed at informing the public. A new feature of the site provides recent writings of various columnists from outside the beltway.

Alternatively, one may "explore the new conservative world" through the Town Hall. Information from more than 20 grassroots organizations like Americans for Tax Reform and Empower America is available from the Town Hall. Links are provided to information from a subject approach of various issues. When using the site's search engine, results may be limited to resources from any or all of these organizations.

The MRC Web page has its roots in a wellrespected organization, provides original information, includes links to other selected conservative sites, and continues to grow. This, combined with its uncluttered layout and easy navigation, makes it a resource to be remembered when looking for the conservative side of an issue-Cindy Etkin, Western Kentucky University Libraries; Cindy.Etkin@wku.edu 


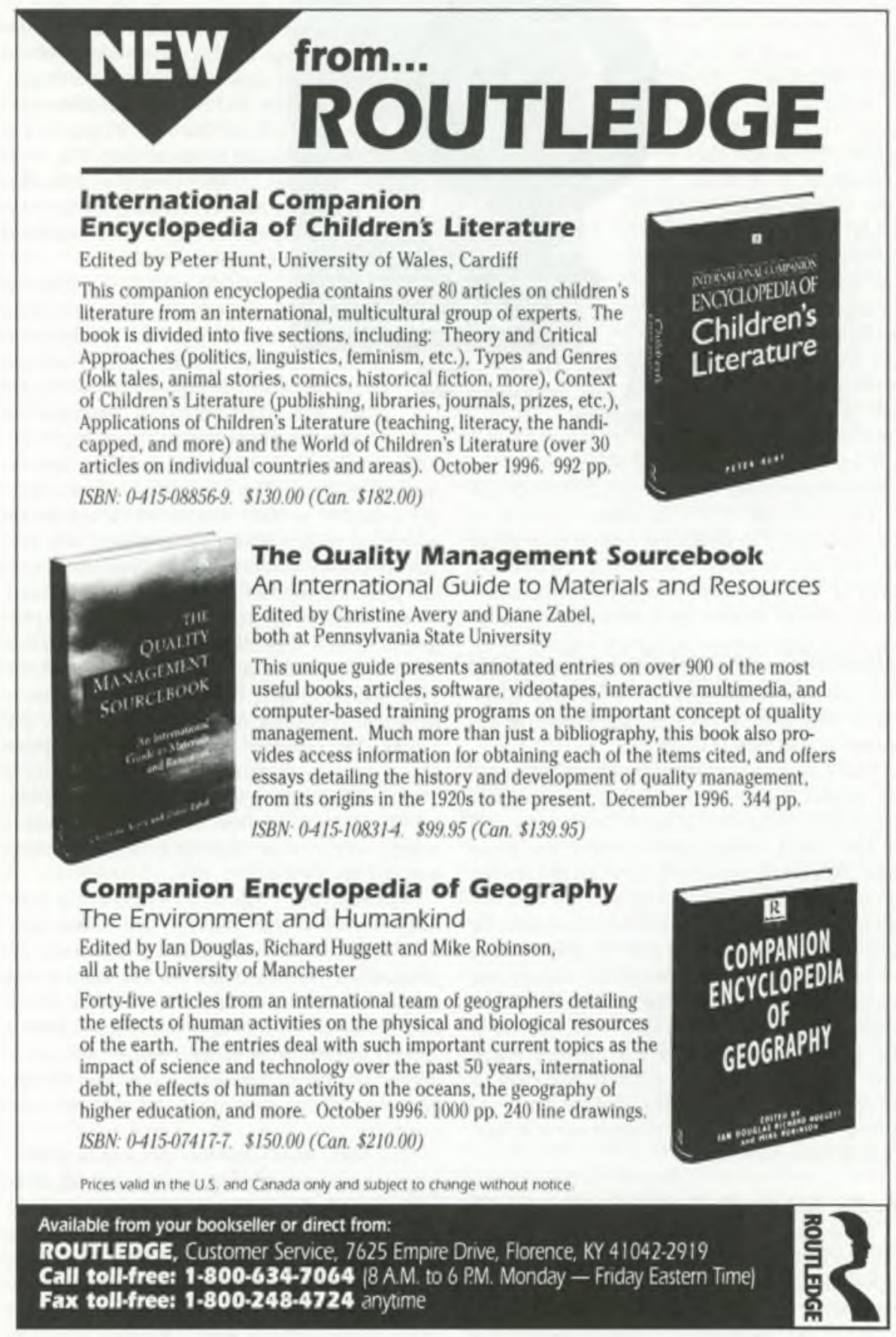

